\author{
초등학교 장애학생의 식생활 지도를 위한 소프트웨어 \\ 개발 및 효과 연구 \\ 최성욱 · 왕유진 · 김두규 ${ }^{+}$ \\ (부산광일초등학교)
}

\title{
A Study of Development and Effectiveness of Eating Habit Teaching Software for Disabilities in Elementary School
}

\author{
Seong-ouk $\mathrm{CHOI} \cdot$ Yoo-jin WANG $\cdot$ Du-gyu $\mathrm{KIM}^{\dagger}$ \\ (Busan Gwang-Il Elementary School)
}

\begin{abstract}
This study put emphasis on improving the quality of lives of the elementary students with disabilities by planning and realizing software for the purpose of teaching eating habits. It tried to develop software which constantly applies and practices contents learned from content systems subordinate to practical subjects. It is mainly consisted of "cooking and eating' among the content systems of the practical subjects in the basic curriculum. To this end, it chose four modules as their final choices, 'eating various foods, cooking happily, setting the table, and washing the dishes.' Media is in CD-ROM Title form. Macromedia Flash and Macromedia Director were used as authoring tools. Program is basically going along centering on small units. And activities in each topic are composed of thinking, investigating, and organizing order. When we applied the software, developed in this research, to 3 elementary students with disabilities using multiple probe design across subjects, it had positive effects on eating habits related functions of all participants.
\end{abstract}

Key words : Student with disabilities in elementary school, Eating habits teaching, Software

\section{I. 서 론}

\section{1. 연구의 필요성}

2007년 특수교육관련법 개정 이후 장애학생 가 족 지원에 대한 요구가 크게 증가하고 있다. 이 는 복지에 대한 관심의 증가와 달리 점차 핵가족 화 되어가고 있는 현대 가족구조 내에서 다른 가 족성원들로부터의 전면적이고 지속적인 지원을 이끌어 내기란 쉽지 않다는 사실을 반증하는 결
과로 보여 진다(교육과학기술부, 2009). 또한 장 애학생들의 경우 가정으로부터 체득이 되어야 할 기본적인 일상생활 기능훈련이 갖추어지지 못한 상태에서 전환환경에 놓이게 됨으로써 이후 접하 게 되는 학교를 포함한 지역사회생활에 이르기까 지 문제를 야기할 수밖에 없는 실정이다(양정혜, 2010).

이에 학교차원에서의 장애학생 교육과 관련하 여 개인, 가정, 사회 등 전 생애에 걸친 생활을

† Corresponding author : 010-5331-2879, kdugy@hanmail.net 
아우를 수 있는 교과의 개발이 시급히 필요하게 되었다. 즉, 지적능력과 지성인을 길러내는 교과 로서, 또는 인간과 인간, 인간과 자원, 인간과 자 연에 대한 탐구 및 아동생활 양식을 길러주는 교 과로서 국어, 수학, 사회, 과학 등의 주요 주지교 육 교과가 아닌 실과교육이 이상의 내용을 충족 시킬 수 있는 대안적인 교과로 대두되고 있다(김 자경, 정남용, 2001; 이시원, 2009).

이런 시대적 요구에 따라 2008년 특수학교 교 육과정의 개정과 함께 장애학생 지원을 위한 기 본교육과정에도 실과과목이 새로이 신설되기에 이르렀다. 그러나 시기적으로 급작스럽게 개발, 보급되었다는 점에서 다소 현장 적용상의 문제점 에 노출될 수밖에 없다는 약점을 가지고 있는 것 이 사실이다. 또한 통합학급 상황 하에서는 장애 학생의 개별적인 요구에 부합하여 교육과정의 접 근이 어려운 것이 사실이다. 이에 더하여 실과가 새로이 신설된 교과이다 보니 교실장면에서 장애 학생을 대상으로 적용 효과를 검증한 연구 및 프 로그램 개발은 전무한 실정이다. 따라서 특수학 급에서 장애학생들의 실생활과 학습에 대한 요구 를 모두 충족시켜줄 수 있도록 구성된 프로그램 의 개발 및 적용이 시급하다 하겠다.

이에 본 연구에서는 단위학급 내에서 교육과정 과 연계하여 쉽게 적용 가능한 소프트웨어를 개 발하여 장애학생의 학습효과 및 가정생활에 필요 한 식생활능력을 배양시키고자 하였다. 이를 구 체적으로 실현하기 위해 실과교과의 세 가지 하 위 생활영역(나의 가족과 진로, 가정생활, 기술의 세계) 중 가정생활영역을 중심으로 소프트웨어를 제작하였다. 본 연구는 식생활 지도를 위한 소프 트웨어 설계 및 구현을 통해 초등학교 장애학생 의 삶의 질을 향상시키는데 주안점을 두어 진행 되었다.

\section{2. 연구 문제}

본 연구의 목적은 초등학교 장애학생의 효율적
이고 기능적인 실과교육 실현을 위해 식생활기능 향상을 위한 특수교육용 소프트웨어를 개발하고 그 효과를 파악하는 데 있다. 이를 위한 구체적 인 연구문제는 다음과 같다.

첫째, 본 연구에서 개발한 특수교육용 소프트 웨어가 초등학교 장애학생의 여러 가지 음식 기 능에 미치는 효과는 어떠한가?

둘째, 본 연구에서 개발한 특수교육용 소프트 웨어가 초등학교 장애학생의 골고루 먹기 기능에 미치는 효과는 어떠한가?

셋째, 본 연구에서 개발한 특수교육용 소프트 웨어가 초등학교 장애학생의 즐겁게 요리하기 기 능에 미치는 효과는 어떠한가?

넷째, 본 연구에서 개발한 특수교육용 소프트 웨어가 초등학교 장애학생의 상차리기와 설거지 기능에 미치는 효과는 어떠한가?

\section{II. 선행연구 고찰}

\section{1. 식생활}

우리나라의 경우도 산업화와 더불어 점차 식생 활 및 체형이 서구화 되어가는 경향이 있다. 이 의 결과로 초등학생을 비롯하여 중·고등학생에 이르기까지 비만을 나타내고 있는 학생들이 증가 하고 있는 것이 사실이다. 이에 교육과학기술부 를 비롯한 시·도교육청에서는 학생들의 체력증진 을 통해 지·덕·체를 고루 겸비한 인재를 양성하 고자 학교스포츠클럽과 같은 동아리 및 방과후학 교 교육을 강화하고 있는 실정이다(교육과학기술 부, 2012; 권봉안, 권수현, 2011).

이는 장애학생의 경우에도 적용되며, 특히 장 애학생들의 경우 신체적인 손상 및 결함으로 인 해 상대적으로 또래 학생들에 비해 여러 가지 질 병 및 상해에 노출될 위험이 크다는 점에서 자칫 심각한 결과로까지 이어질 수 있다.

그러나 장애학생의 경우 식생활 습관을 배양하 기 위한 기존의 교육방식이 행동을 변화시키는 
데만 주를 두어 진행된 면이 없지 않다. 이는 진 정희 등(2002)과 박영숙 등(2006)이 영양교육의 목적이 단순히 영양에 대한 지식전달에 그치는 것이 아니라 올바른 식생활을 위한 지식과 기술, 현재 식생활 개선의 흥미유발과 개선 의옥, 개선 된 식생활의 유지 및 일반화에 있다고 한 내용과 다르지 않다. 이는 양정혜(2010)의 연구에서도 나 타나 있듯이 요리활동이 그동안 평가절하 되어 온 탓에 교육적인 가치가 높지 않았다는 점과도 연관되어 있다. 또한 실과교과의 부재로 인해 직 업교과에 현 실과교과에 대한 내용이 포함됨으로 인해 직업교과는 중등학교 이후 학생들에게 필요 한 교육이라는 다소 왜곡된 인식 탓에 초등학교 에 재학하고 있는 장애학생들의 경우 이와 관련 한 교육에서 배제되어 온 것이 사실이다. 그러나 특수학급 및 특수학교에서 급식시간을 이루어지 는 식사지도를 포함한 식생활교육의 경우 영양교 육과 식생활 태도, 식습관과는 매우 강한 상관관 계가 있으며, 이를 동시에 고려하여 접근해야지 만 긍정적인 효과를 검증할 수 있는 것으로 보고 되고 있다(권봉안, 권수현, 2011; 양한라, 2000; 이 윤주, 김경미, 장경자, 2000; 정민경, 1999).

\section{2. 식생활 관련 프로그램}

김주민(2003)과 유수연(2008)은 교사 주도의 중 재보다는 자연스런 환경 하에서 장애학생들의 흥 미와 옥구를 이끌어내는 것이 기존 지식을 확장 시키는 데 효율적이라는 점을 들어 통합적 교육 과정 활동으로서 나누어 갖기, 기다리기, 협동하 기 등과 같은 사회적 상호작용 능력을 배양해주 는 요리활동의 중요성을 강조하고 있다.

박민정(2008)은 직접적인 영양교육 실시 이후 아동의 편식교정, 영양지식수용 등에 매우 효과 적인 결과를 나타내었다고 보고하였다.

양정혜(2010)는 요리활동은 단순히 음식을 만 드는 과정만을 의미하는 것이 아니며, 식품의 선 택, 구입, 조리, 시식 등을 포함한 일련의 과정을
거치면서 대상 학생들에게 다양한 경험기회를 제 공한다는 측면에서 노작교육을 통한 실과교육의 이상과도 일치하는 면이 많다고 하였다. 또한 이 를 위해 8회기에 걸친 조리 프로그램을 개발하여 장애아동의 식생활 태도 변화를 살펴보아 긍정적 인 효과가 있는 것으로 보고하였다. 이와 관련한 구체적인 조리 프로그램은 <표 1 >과 같다.

<표 1> 조리 프로그램

\begin{tabular}{|c|c|c|c|}
\hline 회 & 내용 & 특징 & 교육목표 \\
\hline 1 & $\begin{array}{l}\text { 머핀과 } \\
\text { 쉐이크 }\end{array}$ & $\begin{array}{lr}\text { 머핀용 } & \text { 반죽을 } \\
\text { 활용하여 } & \text { 장식, } \\
\text { 계절과일 } & \text { 이용 } \\
\text { 쉐이크 만들기 }\end{array}$ & $\begin{array}{l}\text { 열에 의한 팽 } \\
\text { 창, 맛의 변화, } \\
\text { 색상의 변화 }\end{array}$ \\
\hline 2 & $\begin{array}{c}\text { 궁중 } \\
\text { 떡복이 }\end{array}$ & $\begin{array}{l}\text { 다양한 야채를 } \\
\text { 이용한 전통음식 } \\
\text { 에 대한 이해를 } \\
\text { 도움 }\end{array}$ & $\begin{array}{l}\text { 비슷한 크기로 } \\
\text { 나누기, 편식의 } \\
\text { 교정, 전통음식 } \\
\text { 문화 이해 }\end{array}$ \\
\hline 3 & $\begin{array}{l}\text { 생크림 } \\
\text { 케이크 }\end{array}$ & $\begin{array}{l}\text { 어버이날을 위한 } \\
\text { 이벤트 수업, 세 } \\
\text { 부 장식에서 창 } \\
\text { 의적 능력 개발 }\end{array}$ & $\begin{array}{lr}\text { 다양한 } & \text { 색상 } \\
\text { 이용, } & \text { 비슷한 } \\
\text { 크기로 } & \text { 나누기 }\end{array}$ \\
\hline 4 & 주먹밥 & $\begin{array}{l}\text { 야채를 다지고, } \\
\text { 밥을 섞어서 다 } \\
\text { 양한 모양의 주 } \\
\text { 먹밥 만들기 }\end{array}$ & $\begin{array}{l}\text { 비슷한 크기로 } \\
\text { 자르기 및 만 } \\
\text { 들기 }\end{array}$ \\
\hline 5 & $\begin{array}{l}\text { 샌드위 } \\
\text { 치와 } \\
\text { 과일꽂 } \\
\text { 이 }\end{array}$ & $\begin{array}{l}\text { 잼바르기, 구멍내 } \\
\text { 기, 꽂이에 꽂는 } \\
\text { 요령 익힘 }\end{array}$ & $\begin{array}{l}\text { 재료의 특성 } \\
\text { 관찰, 편식하지 } \\
\text { 않기 }\end{array}$ \\
\hline 6 & $\begin{array}{l}\text { 떡꼬치 } \\
\text { 와 } \\
\text { 어묵 }\end{array}$ & $\begin{array}{l}\text { 꽂이에 꽂고, 양 } \\
\text { 념을 바르는 기 } \\
\text { 술을 익힘 }\end{array}$ & $\begin{array}{l}\text { 양념의 양 조 } \\
\text { 절하기 }\end{array}$ \\
\hline 7 & $\begin{array}{c}\text { 스파게 } \\
\text { 티 }\end{array}$ & $\begin{array}{l}\text { 다양한 무늬의 } \\
\text { 스파게티가 있음 } \\
\text { 을 알고, 분류해 } \\
\text { 볼 수 있음 }\end{array}$ & $\begin{array}{lr}\text { 비슷한 } & \text { 모양 } \\
\text { 분류하기 } & \text { 및 } \\
\text { 조정하기 } & \end{array}$ \\
\hline 8 & $\begin{array}{l}\text { 도띠아 } \\
\text { 피자 }\end{array}$ & $\begin{array}{l}\text { 전자레인지를 이 } \\
\text { 용하여 간단한 } \\
\text { 또띠아 피자를 } \\
\text { 만듬 }\end{array}$ & $\begin{array}{l}\text { 재료를 골고루 } \\
\text { 나누기, 식품의 } \\
\text { 익는 시간 조 } \\
\text { 절하기 }\end{array}$ \\
\hline
\end{tabular}


김정아(2009)와 정소영(2001)은 요리활동이 장 애학생들의 대 - 소근육의 발달, 부적응 행동 개 선에 효과가 있는 것으로 보고하였다. 이 연구결 과는 신체활동에 초점을 두어 진행하였다는 특징 이 있다. 서혜식과 권현분(2008)은 요리활동이 장 애학생들의 사회성 발달에 있어 효과가 있는 것 으로 보고하여 앞서 제시한 김주민(2003)과 유수 연(2008)의 연구를 뒷받침하고 있다. 장애학생들 을 대상으로 한 실과교과의 연구사례가 많지 않 아 그 효과를 단정하기에는 무리한 면이 있으나 일련의 연구들을 종합해보면 요리활동을 통한 식 생활 활동프로그램이 자신감, 성취감을 통한 교 육관계 개선뿐만 아니라 타 교과활동에도 긍정적 인 성취를 이끌어 내는 것으로 나타났다.

\section{3. 장애학생 소프트웨어}

본 연구에서는 초등학교에 재학하고 있는 장애 학생을 대상으로 식생활 소프트웨어 개발 및 효 과를 알아보고자 하였다. 그러나 특수교육 교재 교구를 납품하는 대표적 기업(핑키밍키, 아리수에 듀, 범한시청각교재개발원, ERC edu) 안내서적을 분석해본 결과 기존 특수교육용 소프트웨어의 경 우 대다수가 문해능력과 관련지어 한글 익히기 등의 기초국어 영역에 치우쳐 있거나 수와 연산 등과 같은 기초수학 영역 정도에 머무르고 있는 것으로 파악되었다. 식생활 관련 소프트웨어가 아니더라도 장애학생을 대상으로 한 주요교과 이 외의 소프트웨어는 거의 전무한 실정이었다. 이 와 관련한 구체적인 내용은 <표 2>와 같다. (주핑 키밍키에서 보급하고 있는 생활주제별 학습 $\mathrm{P} / \mathrm{G}$ 의 경우 음식, 과일과 채소 영역으로 2 주제가 배 당되어 있을 뿐이다. 이마저도 유아 수준의 기본 적인 내용에 그치고 있는 실정이다.

이 문제를 해결하고자 본 연구에서는 2010 개 정 기본교육과정 실과교과의 내용을 중심으로 하 여 진행되었다. 이와 관련한 기본교육과정과 국 민공통기본교육과정 실과 내용은 <표 $3>$ 과 같다.
<표 2> 2012년도 납품 소프트웨어 현황

\begin{tabular}{|c|c|c|c|}
\hline 순번 & 소프트웨어명 & 업체명 & 관련교과 \\
\hline 1 & $\begin{array}{c}\text { 기초국어 } \\
\text { 맞춤 활동지 }\end{array}$ & \multirow{5}{*}{$\begin{array}{l}\text { 아리수 } \\
\text { 에듀 }\end{array}$} & 국어 \\
\hline 2 & $\begin{array}{c}\text { 초등영어 } \\
\text { 맞춤 활동지 }\end{array}$ & & 영어 \\
\hline 3 & $\begin{array}{l}\text { 특수학급을 위한 } \\
\text { 도움자료 만들기 }\end{array}$ & & $\begin{array}{l}\text { 창의적 } \\
\text { 체험활동 }\end{array}$ \\
\hline 4 & $\begin{array}{l}\text { 특수학급을 위한 } \\
\text { 동식물 학습백과 }\end{array}$ & & 과학 \\
\hline 5 & $\begin{array}{c}\text { 심층 교과서 속 } \\
\text { 식물 }\end{array}$ & & 과학 \\
\hline 6 & 피코 시리즈 & \multirow{7}{*}{$\begin{array}{l}\text { 핑키 } \\
\text { 밍키 }\end{array}$} & $\begin{array}{c}\text { 국어, 수학, } \\
\text { 과학 등 } \\
\text { 통합교과 }\end{array}$ \\
\hline 7 & $\begin{array}{c}\text { 국어 학습능력 } \\
\text { 배양 } \mathrm{S} / \mathrm{W}\end{array}$ & & 국어 \\
\hline 8 & $\begin{array}{c}\text { 수학 학습능력 } \\
\text { 배양 } \mathrm{S} / \mathrm{W}\end{array}$ & & 수학 \\
\hline 9 & $\begin{array}{c}\text { 생활주제별 } \\
\text { 학습P/G }\end{array}$ & & 통합교과 \\
\hline 10 & $\begin{array}{c}\text { 어린이 경제 } \\
\text { 교육자료 }\end{array}$ & & 사회 \\
\hline 11 & 율동 자료 & & 음악, 체육 \\
\hline 12 & 안전교실 시리즈 & & 국어, 사회 \\
\hline
\end{tabular}

<표 3>의 내용 중 본 소프트웨어에는 가정생 활 영역의 '음식 만들기와 식사하기' 단원의 목 표를 성취하기 위해 균형 잡힌 식사와 올바른 식 습관 형성의 중요성, 적절한 조리 방법, 조리과정 의 절차 알기, 사용되는 조리기구의 종류 및 쓰 임새, 위생적으로 조리하기 등의 하위내용을 포 함하였다.

소프트웨어 개발의 경우 일반화를 고려한다면 개발과정에 드는 수고와 비용에 비해 효율성이 떨어지는 것이 사실이다. 그러나 소수의 학생을 위해 단위학교에서 고가의 아이패드나 갤럽시탭 을 활용하기에는 현실적인 어려움이 많다는 측면 에서 장애학생에게 교과서를 보완할 수 있는 대 체수단으로 소프트웨어의 효용성을 간과할 수는 없을 것이다. 
$<$ 표 3> 기본교육과정과 국민공통기본교육과정 실과 내용

\begin{tabular}{|c|c|c|c|}
\hline \multirow{2}{*}{ 영역 } & \multirow{2}{*}{ 기본 } & \multicolumn{2}{|c|}{ 국민공통 } \\
\hline & & 5학년 & 6학년 \\
\hline $\begin{array}{c}\text { 나의 가족과 } \\
\text { 진로 }\end{array}$ & $\begin{array}{l}\text { 나의 가족 알기 } \\
\text { 나의 진로 생각해 보기 }\end{array}$ & & \\
\hline 가정생활 & $\begin{array}{l}\text { 음식 만들기와 식사하기 } \\
\text { 의류와 침구 관리하기 } \\
\text { 청소하기 } \\
\text { 가전제품 사용하기 } \\
\text { 생활용품 사용하기 }\end{array}$ & $\begin{array}{l}\text { 나의 성장과 가족 } \\
\text { 나의 영양과 식사 } \\
\text { 옷 입기와 관리하기 } \\
\text { 쾌적한 주거환경 }\end{array}$ & $\begin{array}{l}\text { 간단한 음식 만들기 } \\
\text { 간단한 생활용품 만들기 } \\
\text { 생활자원과 소비 }\end{array}$ \\
\hline 기술의 세계 & $\begin{array}{l}\text { 간단한 생활용품 만들기 } \\
\text { 동식물과 함께 생활하기 } \\
\text { 정보 생활 익히기 }\end{array}$ & $\begin{array}{l}\text { 생활 속의 목제품 } \\
\text { 식물과 함께하는 생활 } \\
\text { 정보기기와 사이버 공간 }\end{array}$ & $\begin{array}{l}\text { 생활 속의 전기전자 } \\
\text { 동물과 함께하는 생활 } \\
\text { 인터넷과 정보 } \\
\text { 일과 진로 }\end{array}$ \\
\hline
\end{tabular}

이를 종합해볼 때 식생활 프로그램의 중요성을 언급한 선행연구 결과에서와 같이 장애학생을 대 상으로 교육과정에 충실한 교수-학습용 소프트웨 어를 개발하여 효과를 살펴보는 것은 상당히 중 요한 작업이라고 판단된다.

\section{III. 소프트웨어 개발 방향}

본 연구는 장애학생들이 기본교육과정에 나와 있는 식생활 기능을 효율적으로 학습하기 위한 멀티미디어 자료이다. 소프트웨어의 구성은 [그림 1]과 같다.

소프트웨어는 시작화면, 활동선택, 학습목표, 생각해보기, 알아보기, 정리하기, 도움말, 교사용 지도교안, 학생용 활동지 등으로 구성되어 있다. 여러 가지 음식, 골고루 먹기, 즐겁게 요리하기, 상차리기와 설거지의 네 가지 학습주제로 이루어 져 있으며 각 모듈은 생각해 보기, 알아보기, 정 리하기의 세 단계로 구성되어 있다. 총 일곱 가 지로 이루어진다. 학습주제별 교사용 지도교안과 학생용 활동지를 제공하여 형성평가를 통한 진전 도를 파악할 수 있다는 장점이 있다.

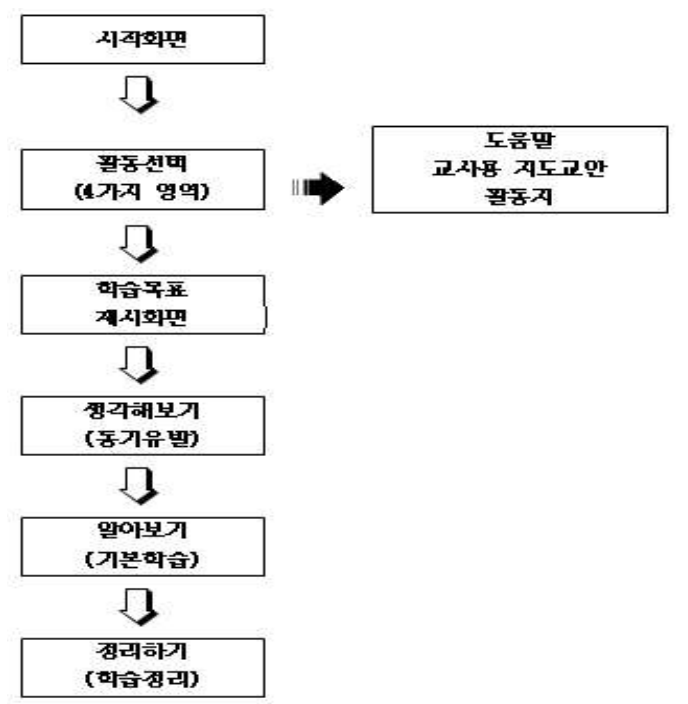

[그림 1] 소프트웨어 구성

\section{1. 소프트웨어의 설계}

본 연구에서 개발한 소프트웨어의 개발 방향, 개발 환경 및 기본구조는 다음과 같다.

가. 소프트웨어의 개발방향

본 연구의 소프트웨어 개발방향은 첫째, 장애 학생들이 적절하게 조리하고, 식사하는 기능을 익히는 것을 목표로 하였다. 둘째, 기본교육과정 
실과교과의 내용에 맞추어 제시된 4 개의 학습 주 제별 독립된 4 개의 모듈로 구성되어 있다. 셋째, 각 모듈은 생각해 보기, 알아보기, 정리하기 단계 로 구성하였다. 넷째, 각 모듈별로 제시되는 문제 및 게임을 통해 학습자의 학습 욕구를 자극하고 적절한 피드백을 제공하도록 하였다. 다섯째, 학 생의 실생활과 밀접한 관련이 있고 관심을 가질 수 있는 내용으로 콘텐츠를 구성하였다. 여섯째, 학습자의 자율학습뿐만 아니라 수업 시 교사가 사용할 수 있도록 수업교안 및 지도 자료를 탑재 하여 효율성 높은 콘텐츠를 개발하는 데 주를 두 었다.

나. 소프트웨어의 개발환경

본 연구의 개발환경은 다음 <표 $4>$ 와 같다. 저 작도구는 Macromedia Flash, Macromedia Directer를 사용하였다. 소프트웨어는 Microsoft Windows XP, Macromedia Flash MX 8.0, Macromedia Director MX, sony vegas 8.0, Adobe Illustrator 10.0, Fractal Design Painter 7.0, Swish 2.0를 사용하여 구안하였다.

하드웨어는 $\mathrm{CPU}$ 는 Amd $2.66 \mathrm{GHz}$, 메모리는 $4 \mathrm{~GB}$, 하드 디스크는 $720 \mathrm{G}$, 비디오 카드는 Nvidia Geforce 8600, 사운드 카드는 Sound Blaster, 모니터는 21" Xvga Color, CD-ROM는 LG 52X, 스캐너는 GT-9000, 디지털 비디오카메 라는 SV-D3000을 사용하여 개발하였다.

다. 소프트웨어의 기본구조

본 소프트웨어의 기본구조는 다음과 같다. 소 프트웨어 구동 시 시작화면이 나오며 본 연구에 서 새로이 제작한 푸름이라는 캐릭터가 나와푸 름이와 함께하는 알기 쉬운 가정생활이라는 제 목에 대해 설명을 한다. 학습자는 푸름이의 설명 에 따라 화면을 클릭하면 네 가지 영역의 하위 활동을 선택하면 해당 화면으로 이동한다. 이동 시 해당영역의 학습목표가 제시되며, 이후 동기 유발에 해당하는 생각해보기, 기본학습에 해당하 는 알아보기, 학습정리에 해당하는 정리하기의
<표 4> 소프트웨어 개발환경

\begin{tabular}{|c|c|c|}
\hline $\begin{array}{l}\text { 저작 } \\
\text { 도구 }\end{array}$ & \multicolumn{2}{|c|}{ Macromedia Flash, Macromedia Director } \\
\hline \multirow{10}{*}{$\begin{array}{l}\text { 하드 } \\
\text { 웨어 }\end{array}$} & $\overline{\mathrm{CPU}}$ & Amd $2.66 \mathrm{GHz}$ \\
\hline & 메모리 & $4 \mathrm{~GB}$ \\
\hline & 하드디스크 & $720 \mathrm{G}$ \\
\hline & 비디오 카드 & NVIDIA GEFORCE 8600 \\
\hline & 사운드 카드 & SOUND BLASTER \\
\hline & 모니터 & $21 "$ XVGA COLOR \\
\hline & $\mathrm{CD}-\mathrm{ROM}$ & LG 52X \\
\hline & CD RW & NICO 16X \\
\hline & SCANNER & GT-9000 \\
\hline & 디지털 비디오 카메라 & SV-D300 \\
\hline \multirow{7}{*}{$\begin{array}{l}\text { 소프 } \\
\text { 트웨 }\end{array}$} & \multicolumn{2}{|c|}{ Microsoft Windows XP } \\
\hline & \multicolumn{2}{|c|}{ Macromedia Flash MX 8.0} \\
\hline & \multicolumn{2}{|c|}{ Macromedia Director MX } \\
\hline & \multicolumn{2}{|c|}{ sony vegas 8.0} \\
\hline & \multicolumn{2}{|c|}{ Adobe Illustrator 10.0} \\
\hline & \multicolumn{2}{|c|}{ Fractal Design Painter 7.0} \\
\hline & \multicolumn{2}{|c|}{ Swish 2.0} \\
\hline
\end{tabular}

세 단계를 거치게 된다. 이외에도 해당 아이콘 및 영역에 대한 설명을 담은 도움말과 교사용 지 도교안 및 학생용 활동지 등이 포함되어 있다. 구체적인 내용은 아래 <표 $5>$ 와 같다.

<표 5> 소프트웨어 기본구조

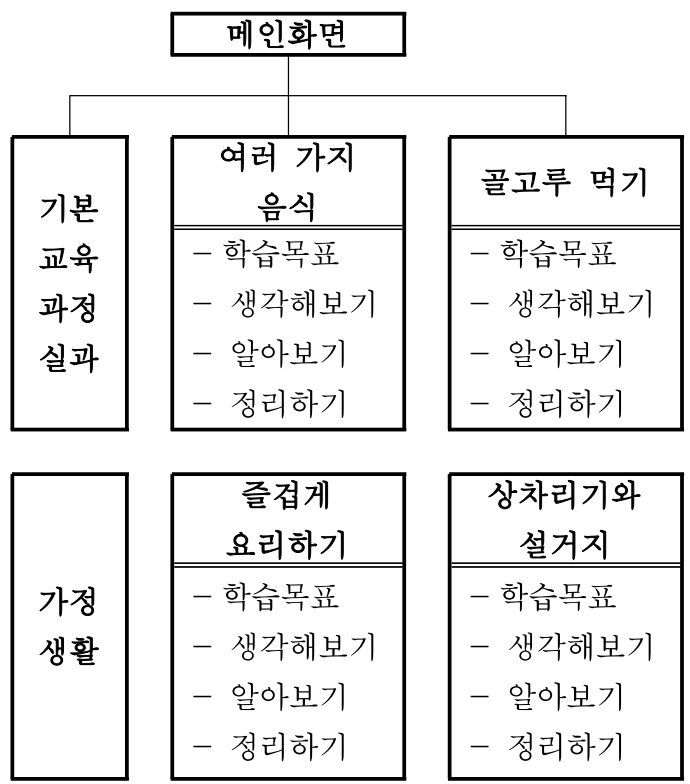




\section{2. 소프트웨어의 구현}

기존에 개발된 소프트웨어의 경우 학습자의 의 도와 상관없이 교수자가 수업도구로 활용하는, 즉 단방향으로 제공되는 형식을 띄고 있는 것이 대부분이었다. 이는 판서 위주의 교육을 탈피하 여 정보화시대의 요구에 부응하고자 한 시도로 보여진다. 그러나 수업장면에서 정보통신기술 (ICT)을 활용한다고 하여 교수자 및 학습자의 교 수-학습 효율성을 보장해준다고 보기는 어렵다. 이에 본 연구에서는 교수-학습자가 동시에 참여 가능한 소프트웨어를 개발하고자 노력하였다. 이 와 관련된 구체적인 내용은 다음과 같다.

첫째, 시작화면이다. 소프트웨어가 구동되면 소 프트웨어 제목(푸름이와 함께하는 알기 쉬운 가 정생활)이 소개된다. 그 다음으로 소프트웨어의 안내를 도와주는'푸름이'라는 캐릭터(동기유발 및 학습의 효율성을 높이고자 본 연구에서 개발한 캐릭터명이다)가 등장한다. 푸름이의 위쪽 화면에 서 길을 따라 아래까지 내려오면 우측 하단의‘학 습시작'아이콘 주위가 반짝거리게 된다. 화면 우 측 하단에는'학습시작’아이콘이 좌측 하단에는'도 움말'아이콘이 위치하게 된다. 이상이 시작화면에 등장하는 애니메이션, 사운드, 그림에 대한 설명 이다. 실제 시작화면은 아래 [그림 2]와 같다.

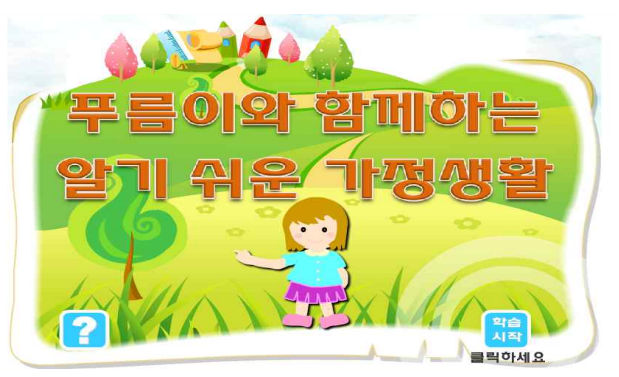

[그림 2] 시작 화면

둘째, 활동선택 화면이다. 본 화면에서는 소프 트웨어의 여러 가지 음식, 골고루 먹기, 즐겁게 요리하기, 상차리기와 설거지로 이루어진 네 가 지 활동 모듈의 주제가 퍼즐 모양으로 제시되어
있다. 이후 푸름이가 등장하여"안녕하세요! 저는 여러분의 학습을 안내할 푸름이라고 해요...(이하 생략)"본 소프트웨어에서 자신의 역할을 소개한 다. 화면 상단에는 소프트웨어의 제목이 소개되 어 있다. 그 아래 사분면상(화면 중간 위치)에 활 동들의 제목이 소개되어 있다. 화면 우측 하단에 는'도움말’아이콘이 좌측 하단에는'학습맵’아이콘 이 위치해 있다. 이상이 활동 선택 화면에 등장 하는 애니메이션, 사운드, 그림에 대한 설명이다. 실제 활동선택 화면은 아래 [그림 3]과 같다.

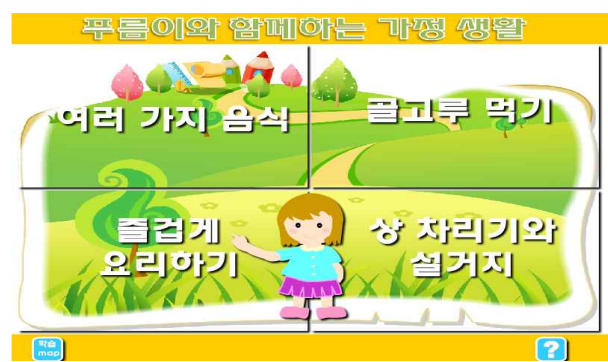

[그림 3] 단원 선택 화면

셋째, 학습목표 제시 화면이다. 푸름이가 활동 주제별로 본 차시의 학습목표를 제시한 후 사라 진다. 학습목표 제시가 끝나면 푸름이는 사라지 고, 칠판위의 글자를 클릭하라는 글귀가 나타난 다. 이상이 학습목표 제시 화면에 등장하는 애니 메이션, 사운드, 그림에 대한 설명이다. 실제 학 습목표 제시 화면은 아래 [그림 4]와 같다.

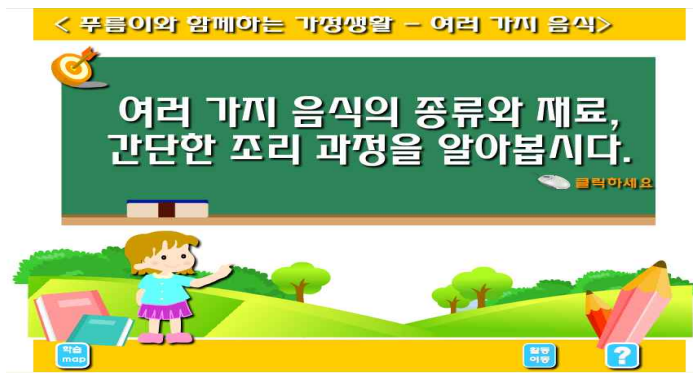

[그림 4] 학습 목표 제시 화면

넷째, 생각해보기 화면이다. 푸름이가 화면에 나타난 번호에 대하여 설명한 후 왼쪽 번호를 클 
릭해보라고 안내한다. 학습자는 해당 번호를 클릭 한 후 우측 화면에 제시되는 사진을 보며 본 활동 에서 교사가 의도하는 것이 무엇인지 생각해보게 된다. 화면 아래에는 6 개의 아이콘이 제시된다. 좌 측부터 아이콘의 제목을 제시하면 다음과 같다. 학습맵, 생각해보기, 알아보기, 정리하기, 활동 이 동, 도움말 순이다. 이상이 생각해보기 화면에 등 장하는 애니메이션, 사운드, 그림에 대한 설명이 다. 실제 생각해보기 화면은 아래 [그림 5]와 같다.

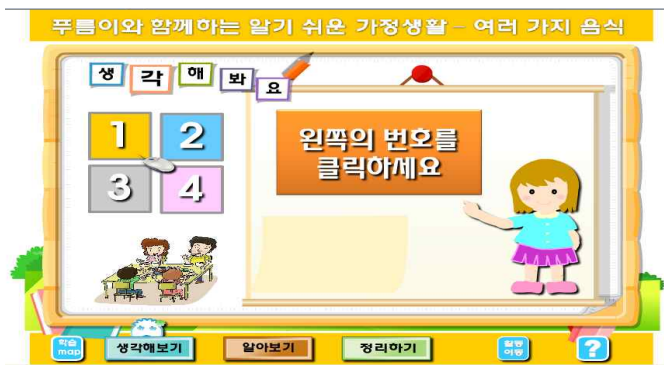

[그림 5] 생각해보기 내용 화면

다섯째, 알아보기 화면이다. 화면 상단에는 소 프트웨어의 제목이 제시되어 있다. 화면 하단의 '알아보기'아이콘을 클릭하면'알아봅시다'화면으로 이동한다. 화면에는 본 활동 주제를 구체적으로 알아보기 위한 하위 내용이 세 가지씩 제시된다. 각각의 하위 내용을 클릭해보면 다음 페이지로 이동하며, 푸름이의 안내를 받게 된다. 학습자는 푸름이의 안내에 따라 해당 되는 부분을 클릭하 여 학습을 진행하면 된다. 각각의 부분 클릭 시 사진 및 동영상과 설명을 들으며 내용을 숙달해 나간다. 학습 종료 시 좌측 상단의'닫기'아이콘을 클릭하면'정리하기'메인 화면으로 이동하게 된다. 화면 아래에는 6 개의 아이콘이 제시된다. 좌측부 터 아이콘의 제목을 제시하면 다음과 같다. 앞서 생각해보기와 동일하게 학습맵, 생각해보기, 알아 보기, 정리하기, 활동 이동, 도움말 순으로 제시 된다. 학습이 끝난 후 화면 하단의'정리하기'아이 콘을 클릭하면 다음 화면으로 이동하게 된다. 이 상이 알아보기 화면에 등장하는 애니메이션, 사
운드, 그림에 대한 설명이다. 실제 알아보기 화면 은 아래 [그림 6]과 같다.

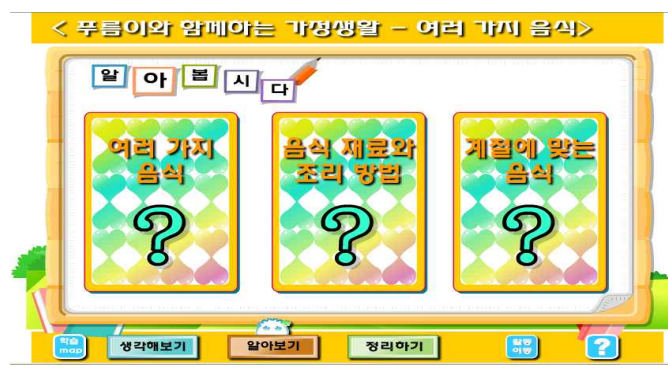

[그림 6] 알아보기 메인 화면

여섯째, 정리하기 화면이다. 화면 상단에는 소 프트웨어의 제목이 제시되어 있다.'알아봅시다'화 면과 동일하게 화면에는 본 활동 주제를 구체적 으로 알아보기 위한 하위 내용이 세 가지씩 제시 된다. 각각의 하위 내용을 클릭해보면 다음 페이 지로 이동하며, 푸름이의 안내를 박아 학습을 진 행하게 된다. 이동버튼을 클릭해가며 주어진 내 용을 반복 학습할 수 있도록 구성되어 있다. 화 면 아래에는 6 개의 아이콘이 제시된다. 좌측부터 아이콘의 제목을 제시하면 다음과 같다. 학습맵, 생 각해보기, 알아보기, 정리하기, 활동 이동, 도움말 순으로 제시된다. 학습 종료 시 좌측 상단의'닫기' 아이콘을 클릭하면'정리하기'메인 화면으로 이동하 게 된다.'정리하기'메인 화면으로 이동하면서'참 잘 했습니다.'라는 문구와 함께 해당 문구에 대해 푸름 이의 안내가 시작된다. 이상이 정리하기 화면에 등 장하는 애니메이션, 사운드, 그림에 대한 설명이다. 실제 정리하기 화면은 아래 [그림 7]과 같다.

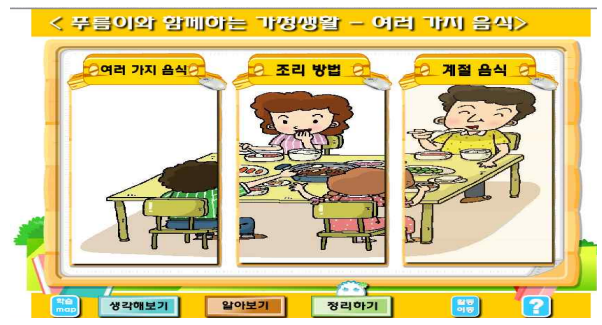

[그림 7] 정리하기 메인 화면 
일곱째, 확인 학습 및 게임 화면이다.'정리하기' 메인 화면에서'참 잘했습니다.'라는 문구를 클릭 하면 본 차시의 내용을 평가하는 문제 및 게임이 실행되게 된다. 이를 통해 학습자는 자연스럽게 활동 주제를 익히게 되며, 미진한 부분은 언제든 지'활동 이동'아이콘을 눌러 해당되는 내용으로 이동가능하다. 이상이 확인 학습 및 게임 화면에 등장하는 애니메이션, 사운드, 그림, 사진, 동영상 에 대한 설명이다. 실제 확인 학습 및 게임 화면 은 아래 [그림 8], [그림 9]와 같다.
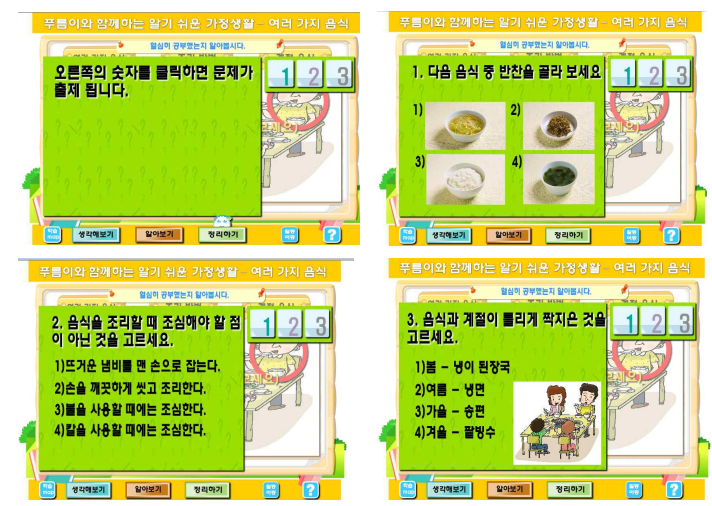

\section{[그림 8] 확인학습 화면}

여덟째, 기타 화면이다. 소프트웨어를 활용하는 동안 자신의 학습 위치를 알고 싶다면 좌측 하단 의 '학습맵'아이콘을 클릭하면 된다. 화면이 이동 하며 자신의 위치가 원안에 깜빡거린다.'도움말' 아이콘을 클릭하면 지도 교안 및 학습지 파일 탑 재 화면으로 이동하게 된다. 소프트웨어를 교육 활동 시에 활용하여 수업의 효과를 극대화시킬

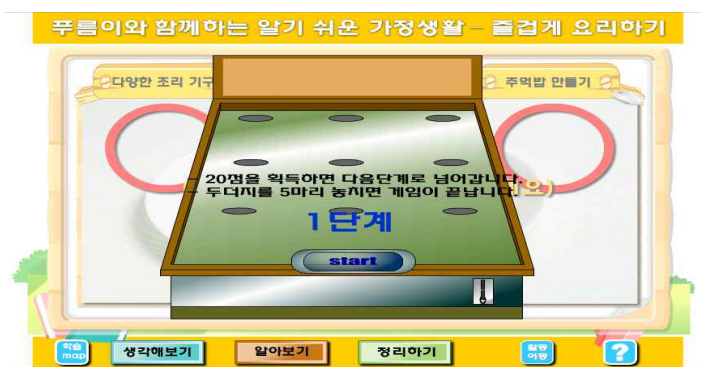

[그림 9] 게임 화면
수 있도록 지도안 및 학습지를 PDF 파일로 실어 두었다. 또한도움말'아이콘을 클릭하면 소프트웨 어에 사용되는 아이콘들에 대한 설명 화면으로 이동하게 된다. 지도안 및 학습지를 $\mathrm{PDF}$ 파일(예 시)은 <표 6>, <표 7>과 같다.

<표 6> 지도안 예시 자료

\begin{tabular}{|c|c|}
\hline 참고 & $\begin{array}{c}\text { ·개정 특수학교 교육과정 실과 } \\
\text { 개넌헌 특수학교 교육과정 직업 }\end{array}$ \\
\hline
\end{tabular}

<표 7> 활동지 예시 자료

\begin{tabular}{|c|c|c|c|}
\hline 과목명 & $\begin{array}{c}\text { 기본교육과정 } \\
\text { 실과 }\end{array}$ & 대상학생 & 장애학생 \\
\hline 관련 & $\begin{array}{c}\text { 기본교육과정 } \\
\text { 직업 }\end{array}$ & 학습유형 & 생각해 보기 \\
\hline 원명 & \multicolumn{3}{|c|}{7 1. 여러 가지 음식 } \\
\hline 비물 & \multicolumn{3}{|c|}{ 소프트웨어, TV, 컴퓨터, 마우스 } \\
\hline 학습 & \multicolumn{3}{|c|}{$\begin{array}{l}\text { 여러 가지 음식의 종류에 대해 알아봅시다. } \\
\text { 상상력을 발휘할 수 있다. } \\
\text { 사고력을 기를 수 있다. }\end{array}$} \\
\hline 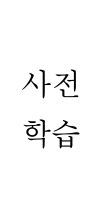 & \multicolumn{3}{|c|}{$\begin{array}{l}\text { 무엇을 음식이라고 하는지 알아본다. } \\
\text { 왜 매일 음식을 먹어야 하는지를 이해할 } \\
\text { 수 있도록 지도한다. } \\
\text { ·른 영양소를 섭취하기 위해서는 어떻게 } \\
\text { 해야 하는지 알아본다. }\end{array}$} \\
\hline 학습 & \multicolumn{3}{|c|}{$\begin{array}{l}\text {.여러 가지 음식의 종류와 관련한 동영상 } \\
\text { 내용을 보고 자신의 생각이나 느낌을 표 } \\
\text { 한혼도된 영상과 올바른 영상이 무엇인지 } \\
\text { 이야기해 본다. }\end{array}$} \\
\hline $\begin{array}{l}\text { 지도상 } \\
\text { 의 } \\
\text { 유의점 }\end{array}$ & \multicolumn{3}{|c|}{$\begin{array}{l}\text {-상황에 맞도록 자신의 생각을 표현할 수 } \\
\text { 아쏘육 지기도한다. 의사를 표현할 수 있도록 도와 } \\
\text { 준다. } \\
\text {-학습 활동 시에 장난을 치지 않고 활동에 } \\
\text { 집중할 수 있도록 도와준다. }\end{array}$} \\
\hline 활용. & \multicolumn{3}{|c|}{$\begin{array}{l}\text { 본 프로그램에서 지도한 내용을 바탕으로 } \\
\text { 실생활 내에서 접하게 되는 음식의 종류 } \\
\text { 을 알고, 더 나아가 타 지역 또는 세계 여 } \\
\text { 러 나라마다 다른 음식의 종류를 알 수 } \\
\text { 있도록 한다. }\end{array}$} \\
\hline
\end{tabular}




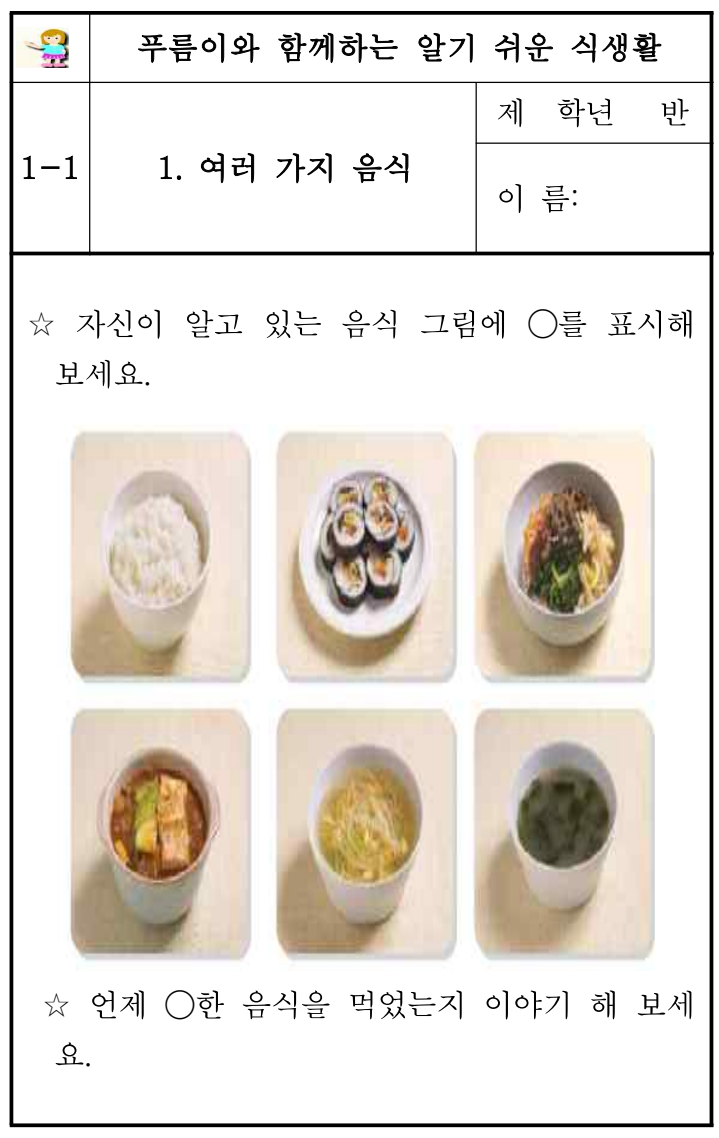

\section{IV. 개발 소프트웨어 적용}

특수학급에 입급되어 있는 장애학생을 대상으 로 본 연구에서 개발한 소프트웨어의 효과를 검 증하였다.

\section{1. 연구대상}

본 연구의 효과를 검증하기 위해 $\mathrm{B}$ 광역시 $\mathrm{G}$ 초 등학교 특수학급에 입급되어 있는 장애학생 8 명 중 일반학급에 완전통합 되어 있는 학생 5 명을 제외한 나머지 3 명의 학생이 연구에 참여하였다. 연구대상에 대한 일반적인 특성은 <표 8>과 같 다.

\section{<표 $8>$ 연구대상의 일반적인 특성}

\begin{tabular}{c|c|c|c|c}
\hline 대상 & 성별 & 학년 & 연령 & 장애유형 \\
\hline \hline $\mathrm{A}$ & 남 & 2 & 10 세 & 지체장애 \\
\hline $\mathrm{B}$ & 남 & 4 & 12 세 & 정신지체 \\
\hline $\mathrm{C}$ & 여 & 5 & 13 세 & 정신지체 \\
\hline
\end{tabular}

$\mathrm{A}$ 학생은 초등학교 2학년이며, 특수교육대상자 (정신지체)로 선정되어 특수학급에서 시간제로 학습지원을 받고 있다. B광역시에 소재한 대학병 원에서 뇌병변 장애 3 급으로 진단받았다. 본 실 험과 관련된 식생활기능의 수준에 있어, 의사소 통이 다소 부자연스럽긴 하나 자주 접하는 음식 의 경우 종류 및 이름을 말할 수 있다. 그러나 자신이 좋아하는 육류 이외의 음식에는 별다른 관심을 보이지 않는 경우가 자주 목격된다. 아직 배식 습관 및 식습관이 제대로 자리 잡지 못한 탓에 줄을 서서 기다리거나 다 먹은 후 잔반을 치우는 활동, 자신이 먹은 자리를 깨끗하게 치우 는 등의 활동에 어려움을 호소하는 경우가 있다. 간단한 조리 기구의 경우 비구어적인 방법으로 가리키는 것으로 보아 조리 기구에 대한 지식을 어느 정도는 갖추고 있는 것으로 판단된다. 아직 상차림이나 요리하는 활동에서는 방법을 몰라 교 사의 도움을 필요로 하거나 어려움을 호소하는 경우가 많이 발생한다. 설거지의 경우에도 신체 협응이 부자연스러운 탓에 옷을 버리거나 주위에 물을 흥건히 튀기는 장면이 자주 목격된다.

$\mathrm{B}$ 학생은 초등학교 4 학년이며, 특수교육대상자 (정신지체)로 선정되어 특수학급에서 시간제로 학습지원을 받고 있다. 특수교육대상자로 선정되 기 이전에 $\mathrm{B}$ 광역시에 소재한 소아청소년정신과에 서 지적장애 1 급으로 진단받았다. 본 실험과 관 련된 식생활기능의 수준에 있어, 여러 가지 음식 의 종류 등을 알고 있긴 하나 이를 능동적으로 표현하는 데 문제를 나타내며, 다그칠 경우 끙끙 거리는 소리를 반복적으로 내며 자신의 오른쪽 겨드랑이 부분의 겉옷을 반복적으로 문지르는 행 동을 보인다. 급식예절은 잘 형성되어 차분하게 
식사하는 모습을 엿볼 수 있다. 그러나 조리 기 구의 이름 및 요리법을 익히는 데는 문제를 나타 내며 자신의 요구가 받아들여지지 않을 때 옆 친 구에게 화를 내는 모습이 자주 목격된다. 상차리 기와 설거지 활동 영역에 있어서는 수행을 거부 하는 상황이 자주 나타난다.

$\mathrm{C}$ 학생은 초등학교 5 학년이며, 특수교육대상자 (정신지체)로 선정되어 특수학급에서 시간제로 학습지원을 받고 있다. B학생과 마찬가지로 특수 교육대상자로 선정되기 이전에 $\mathrm{B}$ 광역시에 소재한 대학병원에서 지적장애 2급으로 진단받았다. 본 실험과 관련된 식생활기능의 수준에 있어, 여러 가지 음식, 골고루 먹기, 즐겁게 요리 하기, 상차 리기와 설거지 모든 영역에 있어 높은 수준은 아 니나 기본적인 수준의 성취는 수행가능하다. 이 는 조부모의 관심과 지속적인 훈련의 결과로 보 인다.

\section{2. 연구 설계}

본 연구에서는 식생활기능 향상을 위해 본 연 구에서 개발된 특수교육용 소프트웨어가 초등학 교 특수학급에 재학 중인 장애학생들의 식생활기 능 수행에 미치는 효과를 파악하고자 대상자간 중다 간헐기초선 설계(multiple probe across participants design)를 사용하였다. 본 연구에서 사용한 중다 간헐 기초선 설계는 기존의 중다 기 초선 설계의 변형된 형태이다. 중다 기초선 설계 가 그 다음 종속변인을 오랜 기간에 걸쳐 측정해 야 하는 단점이 있는데 반해, 중다 간헐 기초선 설계는 기초선 자료를 간헐적으로 측정하여 시간 의 낭비를 막을 수 있다는 장점이 있다(이효신, 2007).

\section{3. 도구}

가. 식생활기능 수행평가 척도

본 연구에서는 초등학교 특수학급에 입급되어 있는 대상학생들의 식생활기능 향상에 미치는 효
과를 알아보고자 연구대상에 대한 식생활기능 수 행평가를 실시하였다. 본 식생활기능 수행평가 척도는 기본교육과정 실과교과의 내용 및 소프트 웨어 내용을 토대로 연구자가 직접 제작하였다. 본 연구자가 기본교육과정 실과교과의 내용 및 소프트웨어 내용을 충실히 반영하여 주제별로 5 문항씩 총 20 문항을 1 차 개발하였으며, 문항 내 용의 타당도를 위해 특수교육학과 교수 2 인과 교 직경력 5 년 이상의 특수교사 3 인에게 의뢰하여 문항에 대한 수정, 삭제를 통한 2차례의 검토 과 정을 거쳤으며, 초등학교 특수학급 학생과 연관 될 수 있는 문항으로 주제별 3 문항씩 최종 12 문 항이 선정되었다. 각 문항별 점수는 대상학생의 수행여부에 따라 수행한 경우는 1점, 수행하지 못한 경우에는 0 점으로 구성되었으며, 주제별 만 점은 3점이다. 구체적인 식생활 수행평가 척도의 내용은 <표 9>와 같다.

<표 9> 식생활기능 수행평가 척도 구성 내용

\begin{tabular}{|c|c|c|c|}
\hline 주제 & 수행평가 항목 & 가 & 부 \\
\hline \multirow{5}{*}{$\begin{array}{l}\text { 여러 } \\
\text { 가지 } \\
\text { 음식 }\end{array}$} & $\begin{array}{l}\text { 여러 가지 음식의 이름을 알고 } \\
\text { 말할 수 있는가? }\end{array}$ & 1 & 0 \\
\hline & 음식의 조리방법을 알고 있는가? & & \\
\hline & (굽기, 튀기기, 삶기, 찌기, 부치 & 1 & 0 \\
\hline & 기 등) & & \\
\hline & $\begin{array}{l}\text { 계절에 맞는 음식을 알고 있는 } \\
\text { 가? }\end{array}$ & 1 & 0 \\
\hline \multirow{3}{*}{$\begin{array}{c}\text { 골고 } \\
\text { 루 } \\
\text { 먹기 }\end{array}$} & $\begin{array}{l}\text { 음식을 골고루 먹었을 때의 좋은 } \\
\text { 점을 알고 있는가? }\end{array}$ & 1 & 0 \\
\hline & $\begin{array}{l}\text { 음식을 골고루 먹었을 때의 나쁜 } \\
\text { 점을 알고 있는가? }\end{array}$ & 1 & 0 \\
\hline & $\begin{array}{l}\text { 나의 식생활 습관을 알고 말할 } \\
\text { 수 있는가? }\end{array}$ & 1 & 0 \\
\hline \multirow{3}{*}{$\begin{array}{c}\text { 즐겁 } \\
\text { 게 } \\
\text { 요리 } \\
\text { 하기 }\end{array}$} & $\begin{array}{l}\text { 여러 가지 조리 기구의 이름을 } \\
\text { 알고 말할 수 있는가? }\end{array}$ & 1 & 0 \\
\hline & $\begin{array}{l}\text { 감자 샌드위치 요리법을 알고 순 } \\
\text { 서대로 말할 수 있는가? }\end{array}$ & 1 & 0 \\
\hline & $\begin{array}{l}\text { 주먹밥 요리법을 알고 순서대로 } \\
\text { 말할 수 있는가? }\end{array}$ & 1 & 0 \\
\hline
\end{tabular}




\begin{tabular}{c|l|l|l}
\hline \multirow{2}{*}{$\begin{array}{c}\text { 상차 } \\
\text { 리기 }\end{array}$} & $\begin{array}{l}\text { 다양한 상차림을 알고 말할 수 } \\
\text { 있는가? (다과상, 한식상 등) }\end{array}$ & 1 & 0 \\
\cline { 2 - 5 } $\begin{array}{c}\text { 솨서에 맞게 설거지를 할 수 있 } \\
\text { 설거 } \\
\text { 지는ㄱ? }\end{array}$ & $\begin{array}{l}\text { 요리와 관련된 여러 가지 직업을 } \\
\text { 말할 수 있는가? }\end{array}$ & 1 & 0 \\
\hline
\end{tabular}

\section{4. 연구 절차}

\section{가. 기초선}

기초선 기간 동안에는 어떠한 교수-학습도 이 루어지지 않았다. 기초선 측정은 대상 아동별로 소프트웨어 적용 전 최소 4 회기 이상 실시하였 다.

\section{나. 중재}

중재는 개발한 소프트웨어를 주 2-3회씩 6주 간, 총 20회기에 걸쳐 대상 학생별로 이루어졌다. 중재는 연구자가 특수학급에서 30 분 정도 실시하 였으며, 대상학생이 선택한 주제를 중심으로 실 시되었으며, 단 각 주제별로 최소 4 회기 이상 중 재가 실시될 수 있도록 연구자가 조정하였다. 중 재는 주제 및 활동목표 제시, 사전활동, 소프트웨 어 활용, 시연, 피드백, 정리 등의 순으로 이루어 졌다.

\section{다. 유지}

유지 기간은 식생활 중심 소프트웨어의 효과를 검증하기 위해 중재 종료 2주 후 기초선과 동일 한 방식으로 대상 학생 별로 5회기 실시하였다.

\section{5. 자료수집}

본 연구에서 대상학생의 식생활기능 수행에 대 한 자료는 특수/통합교사 5명, 학생 부모 4 명에 의해 수집되었다. 자료는 중재를 실시한 날 대상 학생에 대한 학교, 가정 일과의 자연스런 상황에 서 학생의 수행 정도를 관찰한 후 식생활기능 수 행에 대한 점수를 부여하는 방법으로 수집되었 다. 각 자료 수집자의 식생활기능 수행평가 척도
의 점수를 주제내용별로 합산하여 대상학생들의 식생활기능 향상정도를 파악하였다. 9인(특수/통 합교사 5명, 부모 4 명)의 수행평가 척도 점수를 바탕으로 1 회기 획득 가능한 주제별 최고 점수는 27점(3점 $\times 9$ 인)이다.

자료의 신뢰도 확보를 위해 연구자는 연구 참 여 교사 및 부모를 대상으로 대상학생들의 식생 활기능 수행평가에 대한 관찰자 훈련을 실시하였 다. 이를 위해 실험 시작 전 대상학생의 각 주제 별 수행에 대하여 캠코더로 촬영한 자료를 바탕 으로 수행평가 훈련을 실시하였으며 자료수집자 들의 수행평가 일치도가 $95 \%$ 이상이 될 때 까지 훈련을 실시하였다. 총 4 회기 수행평가훈련이 실 시되었으며 최종 일치도는 $97 \%$ 였다.

\section{V. 연구 결과}

\section{1. 여러 가지 음식 기능의 변화}

대상 학생별 여러 가지 음식 기능의 평균과 범 위는 <표 10>, [그림 10]과 같다. 이를 구체적으 로 살펴보면, $\mathrm{A}$ 학생의 경우 기초선 기간 동안의 평균과 범위는 0.5 (범위 $0 \sim 1$ ), 중재 기간 동안은 7.3(범위 0 11), 유지 기간 동안은 8.6(범위 7 9) 로 나타났다. 기초선 기간에 비해 중재 기간은 6.8 증가, 유지 기간은 8.1 증가한 것으로 나타났 다. $\mathrm{B}$ 학생의 경우 기초선 기간 동안의 평균과 범 위는 7.6(범위 7 8), 중재 기간 동안은 15.8 (범위 12 19), 유지 기간 동안은 15.0(범위 14 16)로 나 타났다. 기초선 기간에 비해 중재 기간 동안 8.2 로 상당히 증가하였으며, 중재 종료 이후 유지기 간 동안에도 7.4 증가한 것으로 나타났다. C학생 의 경우 기초선 기간 동안의 평균과 범위는 7.3 (범위 6 8), 중재 기간 동안은 14.8(범위 9 20), 유지 기간 동안은 15.6(범위 15 16)로 나타났다. 기초선 기간에 비해 중재 기간 동안 7.5 로 상당 히 증가하였으며, 중재 종료 이후 유지기간 동안 에도 8.3 증가한 것으로 나타났다. 3 명의 학생의 
데이터를 비교해보면 중재기간에는 $\mathrm{B}$ 학생이 유지 기간에는 $\mathrm{C}$ 학생이 근소한 차이긴 하나 가장 높 은 성취를 나타낸 것으로 나타났다.

대상 학생별 여러 가지 음식 기능의 경우 중재 전 $\mathrm{A}$ 학생은 자신이 자주 접하는 음식 이외에는 음식의 이름 및 생김새를 구별하지 못하였을 뿐 만 아니라 선호하는 음식이외에는 관심을 두지 않는 장면이 자주 목격되었다. 또한 음식이 어떤 조리과정을 거쳐 만들어지는지 계절에 맞는 음식 이 무엇인지 알지 못하였다. 그러나 중재 이후에 는 계절별 음식의 종류를 비롯하여 선호하지 않 는 음식에 대해서도 관심을 가지게 되었다. 이는 소프트웨어의 적용을 통해 대상 학생의 단정한 옷차림하기 역량이 강화되었다는 사실을 알 수 있다. $\mathrm{B}$ 학생과 $\mathrm{C}$ 학생의 경우는 중재 전에 비해 중재 회기가 더해갈수록 여러 가지 음식의 종류 및 조리방법들에 관심의 빈도가 큰 폭으로 증가 한 것으로 나타났다. 이는 학습의 효과라고 볼 수도 있으나 그 이전에 제공되지 않았던 자극이 주어짐으로 인해 관심이 증가한 탓도 있는 것으 로 보여 진다.

<표 10> 대상 학생별 여러 가지 음식 기능의 평균과 범위

\begin{tabular}{ccccccc}
\hline \multirow{2}{*}{ 학생 } & \multicolumn{2}{c}{ 기초선 } & \multicolumn{2}{c}{ 중재 } & \multicolumn{2}{c}{ 유지 } \\
\cline { 2 - 7 } & 평균 & 범위 & 평균 & 범위 & 평균 & 범위 \\
\hline \hline $\mathrm{A}$ & 0.5 & $(0 \sim 1)$ & 7.3 & $(0 \sim 11)$ & 8.6 & $(7 \sim 9)$ \\
\hline $\mathrm{B}$ & 7.6 & $(7 \sim 8)$ & 15.8 & $(12 \sim 19)$ & 15.0 & $(14 \sim 16)$ \\
\hline $\mathrm{C}$ & 7.3 & $(6 \sim 8)$ & 14.8 & $(9 \sim 20)$ & 15.6 & $(15 \sim 16)$ \\
\hline
\end{tabular}

\section{2. 골고루 먹기 기능 변화}

대상 학생별 대인관계 유지하기 기능의 평균과 범위는 <표 11>, [그림 11]과 같다. 이를 구체적 으로 살펴보면, $\mathrm{A}$ 학생의 경우 기초선 기간 동안 의 평균과 범위는 4.8 (범위 $4 \sim 5$ ), 중재 기간 동안 은 8.1(범위 4 12), 유지 기간 동안은 9.0(범위 8 10)로 나타났다. 기초선 기간에 비해 중재 기

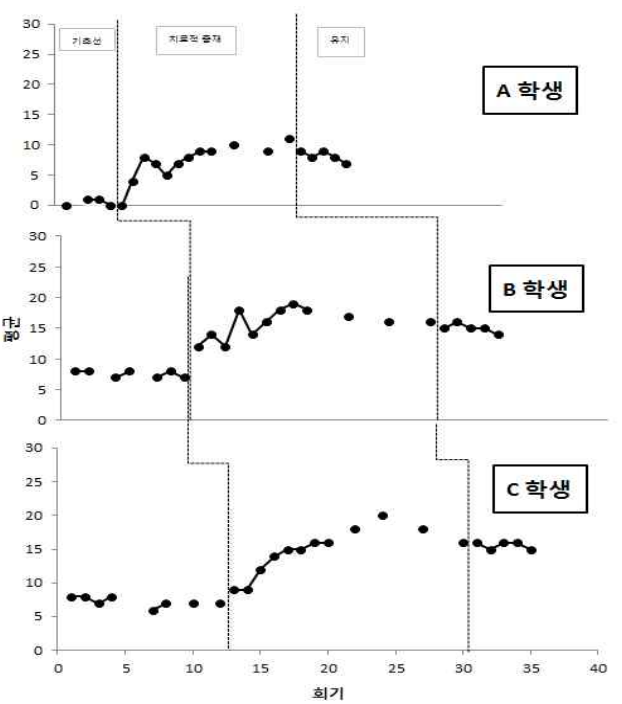

[그림 10] 대상 학생별 여러 가지 음식 기능 의 변화

간은 3.3 증가, 유지 기간은 4.2 증가한 것으로 나타났다. $\mathrm{B}$ 학생의 경우 기초선 기간 동안의 평 균과 범위는 12.1(범위 12 13), 중재 기간 동안은 18.4(범위 16 20), 유지 기간 동안은 18.4(범위 18 19)로 나타났다. 기초선 기간에 비해 중재기 간과 유지기간 동안 각각 6.3 증가하였음을 알 수 있다. C학생의 경우 기초선 기간 동안의 평균 과 범위는 9.5(범위 9 10), 중재 기간 동안은 16.6(범위 10 21), 유지 기간 동안은 18.8(범위 18 20)로 나타났다. 기초선 기간에 비해 중재 기 간은 7.1 증가, 유지 기간은 9.3 증가한 것으로 나타났다.

대상 학생별 골고루 먹기 기능의 경우 중재 전 $\mathrm{A}$ 학생은 교사가“이것 좀 먹어 보렴!”하고 요구하 면 손을 흔들며 안 먹는다는 의사표현을 하였으 나 중재이후 자신이 싫어하는 음식의 경우에도 섭취하는 경우가 증가하였다. $\mathrm{B}$ 학생의 경우 음식 을 제공할 때 인상을 찌푸리며“안 먹어요”라고 대답하는 경우가 자주 목격되었으나 중재 이후에 는 이런 행동의 빈도가 급격히 감소하였으며, 다 른 학생들에게 권하기까지 하였다. 여자인 C학생 
의 경우는 다른 학생과 달리 식습관이 잘 형성되 어 있으며 다른 학생들을 챙기며 나눠먹는 모습 이 자주 관찰되었다.

<표 $11>$ 대상 학생별 골고루 먹기 기능의 평균 과 범위

\begin{tabular}{ccccccc}
\hline \multirow{2}{*}{ 학생 } & \multicolumn{2}{c}{ 기초선 } & \multicolumn{2}{c}{ 중재 } & \multicolumn{2}{c}{ 유지 } \\
\cline { 2 - 7 } & 평균 & 범위 & 평균 & 범위 & 평균 & 범위 \\
\hline \hline $\mathrm{A}$ & 4.8 & $(4 \sim 5)$ & 8.1 & $(4 \sim 12)$ & 9.0 & $(8 \sim 10)$ \\
\hline $\mathrm{B}$ & 12.1 & $(12 \sim 13)$ & 18.4 & $(16 \sim 20)$ & 18.4 & $(18 \sim 19)$ \\
\hline $\mathrm{C}$ & 9.5 & $(9 \sim 10)$ & 16.6 & (10 21) & 18.8 & (18 20) \\
\hline
\end{tabular}

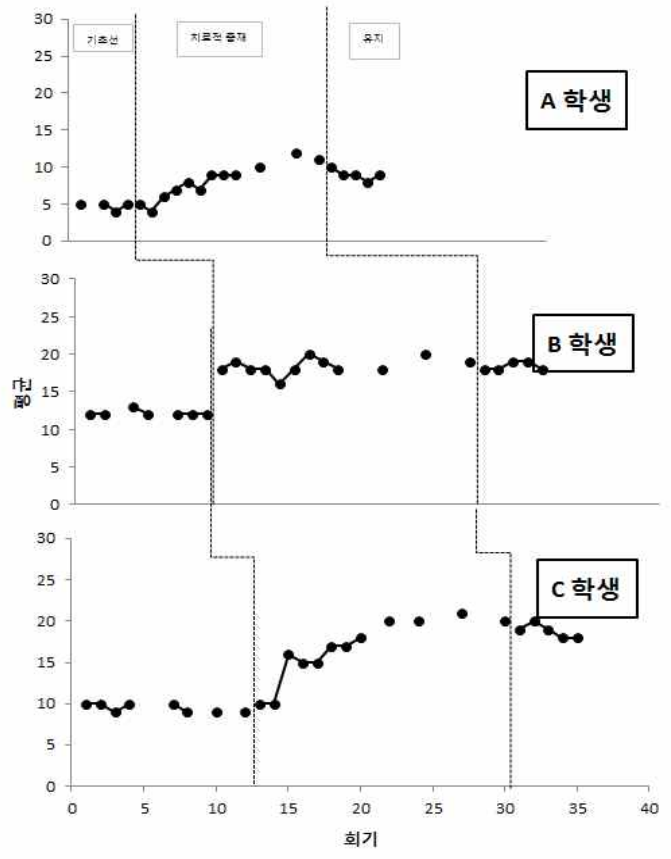

[그림 11] 대상 학생별 골고루 먹기 기능의 변화

\section{3. 즐겁게 요리하기 기능 변화}

대상 학생별 즐겁게 요리하기 기능의 평균과 범위는 <표 12>, [그림 12]와 같다. 이를 구체적 으로 살펴보면, $\mathrm{A}$ 학생의 경우 기초선 기간 동안 의 평균과 범위는 1.8 (범위 1 2), 중재 기간 동안
은 7.9(범위 3 10), 유지 기간 동안은 8.6(범위 8 10)로 나타났다. 기초선 기간에 비해 중재 기 간은 6.1 증가, 유지 기간은 6.8 증가한 것으로 나타났다. $\mathrm{B}$ 학생의 경우 기초선 기간 동안의 평 균과 범위는 11.3 (범위 11 12), 중재 기간 동안은 15.4(범위 13 17), 유지 기간 동안은 15.0(범위 14 16)로 나타났다. 기초선 기간에 비해 중재 기 간 동안 4.1 증가, 유지 기간은 3.7 증가한 것으 로 나타났다. $\mathrm{C}$ 학생의 경우 기초선 기간 동안의 평균과 범위는 10.3(범위 9 11)으로, 중재 기간 동안은 15.3(범위 11 18)로, 유지 기간 동안은 16.0 (범위 15 17)으로 나타났다. 기초선 기간에 비해 중재 기간 동안 5.0 증가, 유지 기간은 5.7 증가한 것으로 나타났다.

대상 학생별 즐겁게 요리하기 기능의 경우 중 재 전 $\mathrm{A}$ 학생은 조리 기구의 이름을 알고 말하거 나 감자 샌드위치, 주먹밥과 요리법을 전혀 알지 못하였으나 중재를 통해 이들에 대한 관심 증가 및 기본적인 기능이 향상된 것으로 나타났다. B 학생은 조부모와 생활하고 있으며, 야간 9시까지 돌봄교실에서 생활하다보니 해당 과업에 노출될 기회가 상대적으로 부족하였다. 중재 이후는 이 런 활동에 흥미를 가지며 능동적으로 친구의 이 름을 부르며 활동에 참여할 것을 권유하는 등 친 구들과의 관계도 향상된 것을 관찰할 수 있었다. $\mathrm{C}$ 학생의 경우는 다른 학생들에 비해 상대적으로 뛰어난 기능을 가지고 있었으며, 중재 이후 기능 이 더 향상된 사실을 알 수 있었다.

<표 $12>$ 대상 학생별 즐겁게 요리하기 기능의 평균과 범위

\begin{tabular}{ccccccc}
\hline \multirow{2}{*}{ 학생 } & \multicolumn{2}{c}{ 기초선 } & \multicolumn{2}{c}{ 중재 } & \multicolumn{2}{c}{ 유지 } \\
\cline { 2 - 6 } & 평균 & 범위 & 평균 & 범위 & 평균 & 범위 \\
\hline \hline $\mathrm{A}$ & 1.8 & $(1 \sim 2)$ & 7.9 & $(3 \sim 10)$ & 8.6 & $(8 \sim 10)$ \\
\hline $\mathrm{B}$ & 11.3 & $(11 \sim 12)$ & 15.4 & $(13 \sim 17)$ & 15.0 & $(14 \sim 16)$ \\
\hline $\mathrm{C}$ & 10.3 & $(9 \sim 11)$ & 15.3 & $(11 \sim 18)$ & 16.0 & $(15 \sim 17)$ \\
\hline
\end{tabular}




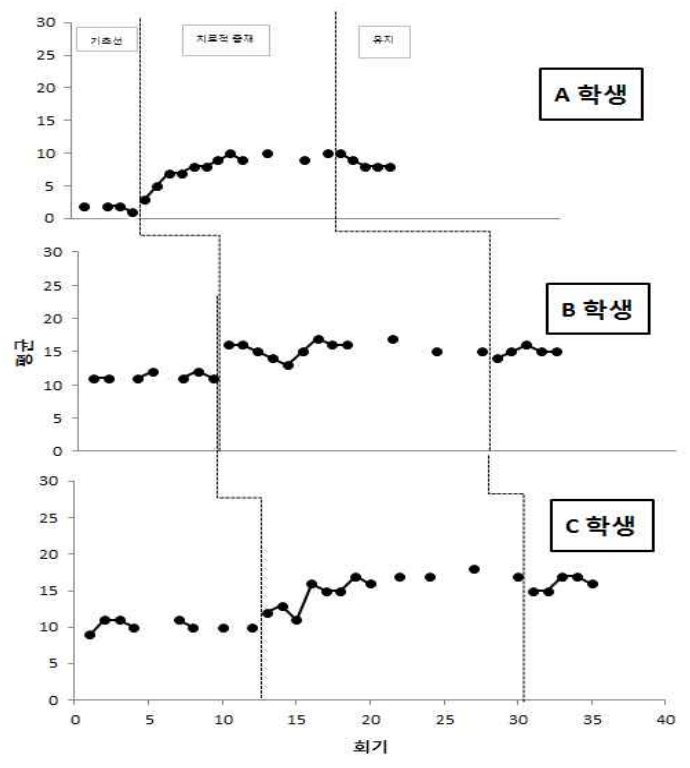

[그림 12] 대상 학생별 즐겁게 요리하기 기능의 변화

\section{4. 상차리기와 설거지하기 기능 변화}

대상 학생별 상차리기와 설거지하기 기능의 평 균과 범위는 <표 13>, [그림 13]과 같다. 이를 구 체적으로 살펴보면, $\mathrm{A}$ 학생의 경우 기초선 기간 동안의 평균과 범위는 0.8 (범위 $0 \sim 1$ ), 중재 기간 동안은 6.4(범위 0 9), 유지 기간 동안은 7.8(범위 7 8)로 나타났다. 기초선 기간에 비해 중재 기간 은 5.6 증가, 유지 기간은 7.0 증가한 것으로 나 타났다. B학생의 경우 기초선 기간 동안의 평균 과 범위는 4.1(범위 4 5), 중재 기간 동안은 11.2 (범위 8 15), 유지 기간 동안은 9.8(범위 9 11)로 나타났다. 기초선 기간에 비해 중재 기간 동안 7.1 증가, 유지 기간은 5.7 증가한 것으로 나타났 다. C학생의 경우 기초선 기간 동안의 평균과 범 위는 6.8(범위 5 9)으로, 중재 기간 동안은 11.6 (범위 7 16)로, 유지 기간 동안은 13.0(범위 12 14)으로 나타났다.

대상 학생별 상차리기와 설거지하기 기능의 경 우 중재 전 $\mathrm{A}$ 학생의 경우 낮은 운동기능을 보인
탓에 상차리기와 설거지하기 활동에서 항상 제외 되어 왔다. 이후 중재를 통해 이런 기회를 제공 받음으로써 책임감 및 상차리기와 설거지하기 관 련 기능의 향상을 가져온 것으로 나타났다. $\mathrm{B}$ 학 생의 경우도 $\mathrm{A}$ 학생과 비슷한 결과를 가져왔다. $\mathrm{C}$ 학생의 경우 경제활동에 종사하시는 조부모와 생활하다보니 위 기능과 관련된 기회에 노출되지 못해 기능이 없는 것으로 판단되어 왔으나 이 단 원의 학습장면에 노출시켜 본 결과 기능 수행이 가능하며 그 수행정도도 다른 학생들과 비교해 뒤처지지 않은 것으로 나타났다.

<표 13> 대상 학생별 상차리기와 설거지하기 기능의 평균과 범위

\begin{tabular}{cccccccc}
\hline \multirow{2}{*}{ 학생 } & \multicolumn{2}{c}{ 기초선 } & \multicolumn{2}{c}{ 중재 } & \multicolumn{2}{c}{ 유지 } \\
\cline { 2 - 7 } & 평균 & 범위 & 평균 & 범위 & 평균 & 범위 \\
\hline \hline $\mathrm{A}$ & 0.8 & $(0 \sim 1)$ & 6.4 & $(0 \sim 9)$ & 7.8 & $(7 \sim 8)$ \\
\hline $\mathrm{B}$ & 4.1 & $(4 \sim 5)$ & 11.2 & $(8 \sim 15)$ & 9.8 & $(9 \sim 11)$ \\
\hline $\mathrm{C}$ & 6.8 & $(5 \sim 9)$ & 11.6 & $(7 \sim 16)$ & 13.0 & $(12 \sim 14)$ \\
\hline
\end{tabular}

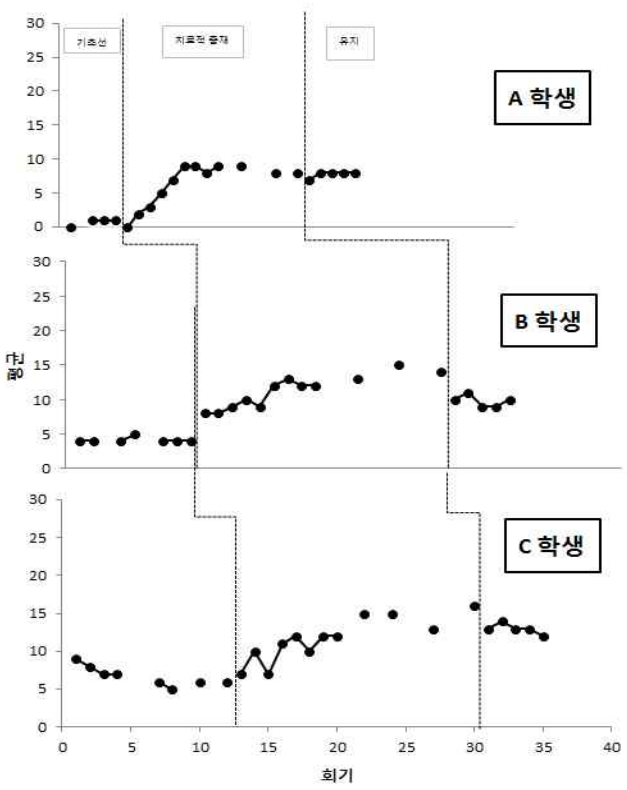

[그림 13] 대상 학생별 상차리기와 설거지하기 기능의 변화 


\section{VI. 결론 및 제언}

본 연구는 학교생활 내에서 가정생활 기술을 습득하는 것이 용이하지 못하다는 점에 착안하여 정신지체 학생들의 음식 만들기, 식사하기에 대 한 지식 및 기능을 향상시켜 사회통합에 필요한 식생활 기술을 배양하는 데 목표를 두어 구안되 었다. 또한 교과서에 맞춰 내용 전개가 이루어질 수 있도록 개정된 기본교육과정 실과 교과서 내 용 및 체계에 최대한 충실하고자 하였다. 연구 결과를 바탕으로 결론을 제시하면 다음과 같다.

첫째, 식생활 소프트웨어는 초등학교 장애학생 의 여러 가지 음식 기능 향상에 효과적이다. 본 연구 결과 중재 이후 대상학생들 모두에서 계절 별 음식의 종류 및 조리방법에 대한 관심이 증가 한 것으로 나타났다. 이는 선행연구들(진정희 등, 2002; 박영숙 등, 2006)에서 식생활 프로그램의 적용결과 올바른 식생활을 위한 지식과 기술, 식 생활 개선의 흥미유발과 개선 의욕이 증가한다는 연구결과와 일치한다.

둘째, 식생활 소프트웨어는 초등학교 장애학생 의 골고루 먹기 기능 향상에 효과적이다. 본 연 구결과 중재 이후 대상학생들 모두에서 간헐적이 긴 하나 편식하는 행동 빈도가 감소한 것으로 나 타났다. 이는 선행연구들(박민정, 2008; 권봉안, 권수현, 2011; 양한라, 2000; 이윤주, 김경미, 장경 자, 2000; 정민경, 1999)에서 영양교육 실시 이후 편식 교정, 식생활 태도 등이 개선되었다는 연구 결과와 일치한다.

셋째, 식생활 소프트웨어는 초등학교 장애학생 의 즐겁게 요리하기 기능 향상에 효과적이다. 본 연구 결과 중재 이후 활동에 조리 기구, 요리 활 동 등에 관심을 보이는 횟수가 증가한 것으로 나 타났다. 이는 양정혜(2010)가 요리 활동과 관련된 일련의 과정을 거치면서 학생들에게 경험을 제공 하였을 때 식생활 태도가 개선되었다는 연구결과 와도 일치한다.
넷째, 식생활 소프트웨어는 초등학교 장애학생 의 상차리기와 설거지 기능 향상에 효과적이다. 본 연구 결과 중재 이후 상차리기와 설거지 같은 기능 수행이 가능하다는 것을 인식함과 동시에 책임감 등의 기능도 증가한 것으로 나타났다. 이 는 선행연구들(권봉안, 권수현, 2011; 박영숙 등, 2006; 양한라, 2000; 이윤주, 김경미, 장경자, 2000; 정민경, 1999 , 진정희 등, 2002)에서 지식 전달에 그치는 것이 아니라 직접 경험을 통해 식 생활 기능이 향상되고 유지된다는 연구결과와 일 치한다.

위의 결론을 중심으로 본 연구의 의의를 제시 하면 다음과 같다.

첫째, 특수학급 및 특수학교에서 손쉽게 활용 할 수 있어 실과 교과에서 제시하는 교육과정 목 표 달성이 보다 용이해질 것으로 판단된다.

둘째, 학습자들이 소프트웨어의 활용을 통해 '음식만들기와 식사하기'에 대한 기본지식 및 기 술을 습득할 수 있을 것이다.

본 연구 결과를 바탕으로 제한점 및 후속연구 에 관한 제언을 하면 다음과 같다.

첫째, 본 연구는 초등학교 장애학생만을 대상 으로 구안되었으나 점차 연구 결과를 다른 학교 (급)으로 확대시켜 나갈 필요가 있겠다.

둘째, 전환교육이라는 차원에서 생애주기별 연 계성을 강화해 나갈 필요가 있음에도 불구하고 기존연구에서는 실과와 직업교과를 연계하려는 의지가 부족하였던 것이 사실이다. 따라서 후속 연구에서는 생애주기별 내용을 고려한 접근이 이 루어져야 하겠다.

셋째, 후속연구에서는 교육매체가 점차 다양화 되고, 실용적으로 바뀌어감에 따라 데스크톱 형 태의 환경에서 벗어나 아이패드나 갤럭시탭 등의 태블릿 형태로 변형을 꾀할 필요가 있다. 


\section{참고 문헌}

교육과학기술부(2009). 기본교육과정 실과. 서울: 대한교과서주식회사.

교육과학기술부(2012). 기본교육과정 실과. 서울: (주미래엔.

교육과학기술부(2009). 특수학교 교육과정. 경기 도 파주: 창원문화.

교육과학기술부(2012). 기본교육과정 실과 교사용 지도서. 서울: (주)미래엔.

권봉안 - 권수현(2011). 영양교사에 의한 영양교육 이 초등학생들의 영양지식, 식습관 및 식행동 에 미치는 영향 비교 연구, 한국스포츠리서치 22(2), 15 25.

김자경 - 정남용(2001). 경도장애학생을 위한 초등 실과교육에서의 학업기술 및 학습전략 교수, 특수교육학연구 36(3), 95 122.

김정아(2009). 통합활동 프로그램이 장애학생에 대한 일반학생의 태도에 미치는 영향, 이화여 자대학교 교육대학원 석사학위 논문.

김주민(2003). 요리활동이 유아의 편식에 미치는 영향, 이화여자대학교 대학원 석사학위 논문.

박민정(2008). 편식교육과정을 위한 영양교육의 효과, 용인대학교 교육대학원 석사학위 논문.

박영숙 - 이정원 · 서정숙 · 이보경 · 이혜상(2006). 영양교육과 상담. 서울: 교문사.

박형서(2011). 실과 교과서 기술의 세계 영역 '동 물과 함께하는 생활' 단원의 화보처리방식 분 석, 수산해양교육연구 23(4), 549 .

서혜식 - 권현분(2008). 정신장애인의 요리활동 프 로그램에 대한 현상학적 연구, 사회복지개발연 구 14(2), 101 117.

소원근 - 김하균(2012). m-learning의 동기화요인 이 학습성과에 미치는 영향, 수산해양교육연구 24(3), 368 377.

양정혜(2010). 실과교과 관련 방과후 요리활동 프 로그램을 통한 장애 아동의 식생활 태도 변화, 초등교육연구 23(1), 163 182.

양한라(2000). 영양교육프로그램이 초등학교 학생 의 영양지식 및 식품섭취의 다양성에 미치는 효과, 창원대학교 교육대학원 석사학위 논문. 유수연(2008). 요리활동을 이용한 또래중재가 자 폐 아동의 사회적 상호작용에 미치는 영향, 이
화여자대학교 대학원 석사학위 논문

이시원(2009). 홀리스틱적 패러다임에 기초한 실 과교육의 성찰, 한국실과교육학회지 22(1), 267 286.

이영숙 - 김유정(2010). 통합적 접근을 통한 실과 식생활교육 프로그램 개발, 한국실과교육학회 지 23(4), 245 267.

이윤주·김경미·장경자(2000). 인천시내 초등학 교 여학생의 영양교육 효과 분석. 대한영양사 회 학술지 6(2), 89 96.

이제화 - 최성욱(2012). 초등학교 장애학생의 진 로 - 직업교육을 위한 소프트웨어 개발 및 효과 연구, 재활복지 16(3), 109 132.

이효신(2007). 응용행동분석. 서울: 학지사.

정민경(1999). 초등학생을 대상으로 한 영양교육 실시 및 효과 평가, 서울여자대학교 대학원 석 사학위 논문.

정소영(2001). 대체행동으로서의 요리활동이 중 도 - 중복장애 아동의 문제행동에 미치는 영향, 인천대학교 교육대학원 석사학위 논문.

주장수·문대영(2009). 실과'우리 생활과 전기· 전자'단원의 교육용 소프트웨어 개발과 적용, 한국실과교육학회지 22(2), 199 212.

진정희 - 이강자·이윤희(2002). 영양교육이 편식 아동에게 미치는 영향: 인천지역 초등학생을 중심으로, 동아시아식생활학회 12(1), 7 14.

채희태(2009). 특수학교 실과 지도를 위한 교사양 성과정에서의 실과교육 운영 방안 모색: 현상 학적 이해를 바탕으로, 중복-지체부자유아연 구 52(4), 91 116.

최지연(2010). 초등학교 교사의 실과 교과서에 대 한 인식, 학습자중심교과교육연구 10(3), 527 548.

함승연(2011). 실과(기술·가정) 학습부진학생 학습 능력향상에 대한 학교급 및 가족유형별 인식, 수산해양교육연구 23(4), 643 648.

현동림 - 김은길 - 김종훈(2011). 안드로이드 기반 사고 공유 마인드맵 애플리케이션 구현, 수산 해양교육연구 23(2), 234 243.

- 논문접수일 : 2012년 10월 11일

- 심사완료일 : 1차 - 2012년 11월 27일

- 게재확정일 : 2012년 11월 30일 